\title{
Očaj i sreća u doba nesreće: raznolikost ženskih doživljaja karantene za vrijeme COVID-19 pandemije
}

\author{
Marija Brajdić Vuković \\ Institut za društvena istraživanja u Zagrebu, Hrvatska \\ e-mail:marija@idi.hr
}

\author{
Karin Doolan \\ Sveučilište u Zadru, Odjel za sociologiju, Hrvatska \\ e-mail:kdoolan@unizd.hr
}

SAŽETAK Pojmovi pandemijskih društvenih praksi, kapitala i ekonomije brige uokviruju ovaj rad koji se bavi osjećajima, mislima i praksama žena tijekom karantene u prvom valu pandemije bolesti COVID-19 u travnju 2020. godine u Hrvatskoj. Temelji se na uvidima dobivenima online istraživanjem u kojem je sudjelovalo 213 visokoobrazovanih žena različite dobi. Postavljena pitanja bila su otvorena i omogućavala prikupljanje osobnih narativa: tražene su ključne riječi za koje sudionice smatraju da dobro opisuju svijet, njihovu obitelj i prijatelje te njih same za vrijeme pandemije kao i iskustva svakodnevnice i razmišljanja o vlastitom životu i budućnosti u kontekstu pandemije. Nalazi ovog istraživanja pokazuju da responzivne pandemijske prakse prožimaju svakodnevnicu žena u karanteni, da su njihovi životi u karanteni rutinirani, emotivno kompleksni, kao i da su žene s malom djecom premorene i preopterećene te da karantena naglašava rodne nejednakosti. Odgovori sudionica također ilustriraju otpornost u kriznoj situaciji zahvaljujući dostupnim materijalnim resursima, ali i kako su neke od njih u prekarnim pozicijama i zabrinute za moguću nepovoljnu promjenu svog ekonomskog statusa. Otpornosti nekih od njih doprinose i kvalitetni odnosi s drugima kao i njihovi hobiji, koji uključuju vježbanje online joge ili pak online kulturne sadržaje. Učinci pandemije prema našim sugovornicama mogu uključivati ekonomsku krizu, produbljivanje nejednakosti, ograničenja ljudskih sloboda te otuđenost među ljudima, ali i veću brigu za prirodu, politički i ekonomski zaokret prema održivijem društvu te jačanje solidarnosti.

Ključne riječi: ženski narativi, karantena, COVID-19, pandemijske prakse, kapitali, rodne nejednakosti. 
Urgentne javnozdravstvene situacije rijetko se istražuju u vrijeme kad se dogadaju. No to bi trebalo raditi. Rhodes i Lancaster (2020.: 177).

\section{Uvod}

Tijekom ožujka 2020. godine prvi put u novijoj povijesti hrvatska je Vlada uvela mjere ograničavanja rada i kretanja ljudi, kao i dostupnosti brojnih društvenih usluga. Te mjere odgovor su na posljedice koje na ljudski život i zdravlje, i zdravstveni sustav u cjelini, ima širenje epidemije SARS-CoV-2 virusa. Poznatiji kao koronavirus, što je generičko ime porodice virusa u koju onaj koji je izazvao pandemiju bolesti COVID-19 spada, u Hrvatskoj je kolokvijalno poznat također u svojoj skraćenoj inačici: korona. Zatvaranje u izolaciju vlastitog doma te dominantna upućenost na svoj samački ili obiteljski život, uz praćenje medija i novosti povezanih s pandemijom, učinili su iskustvo svakodnevnice drugačijim, posebno za vrijeme tzv. prvog, proljetnog vala, koji je i u fokusu ovog rada. Iako će ova krizna situacija biti najvidljivija u posljedicama koje će za sobom ostaviti u budućnosti, snalaženje građana kroz cijeli vijek krize važno je društveno pitanje.

Bivajući i same u ,izolaciji“ vlastitog doma, zajedno smo s grupom kolega-prijatelja ${ }^{1}$ došle do zaključka da je važno zabilježiti ovaj trenutak u životima ljudi i iz njega naučiti o otpornosti na krizne društvene događaje. U uvjetima propisanih epidemioloških mjera bilo je nemoguće i pomišljati na bilo kakvo drugačije nego online, dopisno istraživanje, te je ovaj rad nastao na analizi materijala prikupljenog upravo takvim istraživanjem. U samoj konstrukciji instrumenta oslanjale smo se na iskustva do sada stečena u kvalitativnim istraživanjima, tražeći načine na koje bismo najbolje mogle potaknuti sudionike/ce da izraze, u onoliko rečenica koliko žele, što osjećaju, misle i rade za vrijeme karantene. Pritom nismo bile vođene specifičnom teorijom, iako se teško može reći da je istraživanje koje nastaje kao produkt misli dviju sociologinja koje već petnaestak godina djeluju u struci - teorijski neinformiran. No istraživanje je bilo izviruće u svome najširem smislu, te je teorijsko promišljanje i smještanje dobivenih uvida u najrecentniju literaturu, objavljenu u ovoj pandemijskoj godini, uslijedilo tek nakon prikupljanja iskaza sudionica i sudionika.

Pandemijske prakse, sržna ekonomija ili ekonomija brige i kapitali uokviruju ovaj rad te razrada tih pojmova čini uvod u naš istraživački pothvat. Slijedi prikaz odabranih recentnih istraživanja o društvenim aspektima pandemije COVID-19, a zatim prikaz provedenog istraživanja uključujući pojedinosti o postavljenim pitanjima, etičkim aspektima istraživanja te pristupu analizi dobivenih odgovora. Nalazi su prikazani prema četiri teme: karantena kao kompleksno emotivno iskustvo, pandemijske prakse,

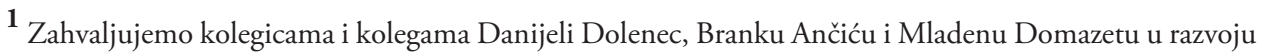
ideje i potpori u provođenju istraživanja. 
pomagači u prilagodbi te izvorišta i učinci pandemije. Konačno, u diskusiji i zaključku promišljamo o značenjima nalaza i kako korespondiraju s nalazima sličnih istraživanja.

\section{Pandemijske prakse, sržna ekonomija, ili ekonomija brige i kapitali}

Teorije društvene prakse potpadaju pod kulturalne teorije, koje društvenu akciju objašnjavaju i razumiju kroz simboličke strukture značenja. U tome se one znatno razlikuju od normativnih i ekonomskih teorija, koje akciju razumiju kroz svrsishodno racionalno djelovanje i normativno djelovanje pojedinaca. U tom su smislu teorije prakse oblikovane kroz analizu društvene prakse, iskustava koje pojedinci imaju s praksama i značenjima koja im pridaju. Za razliku od teorija koje pojedinca vide upravljanim vlastitim interesima, svrhom i intencijama (homo economicus) ili normama i vrijednostima (homo sociologicus), teorije prakse vide pojedinca upravljanog simboličkim strukturama znanja koje omogućuju ili onemogućuju interpretiranje svijeta prema određenim formama. Društvene su prakse ponavljane tjelesne aktivnosti, ali i kontinuirani procesi stvaranja smisla utemeljeni na mreži činjenja i govorenja (vidi npr. Hillebrandt, 2014.; Nicolini, 2016.; Reckwitz., 2002.; Schatzki, 2005.). Rezkowitz (2002.) opisuje društvene prakse kao rutinirane tjelesne performanse, poput kuhanja, odlaska do dućana, igranja nogometa ili vježbanja joge. U isto vrijeme one su set mentalnih aktivnosti i rutinirani načini razumijevanja svijeta te znanja kako što napraviti. Tko izvodi društvenu praksu mora preuzeti i tjelesne i mentalne obrasce koji čine tu praksu. No, da bi pojedinac to mogao, mora imati znanje o toj društvenoj praksi. U tom smislu i tjelesno i mentalno u svojoj je srži društveno jer znanje o tome što čini pojedinu društvenu praksu je društveno znanje. Stvari su također nerazdvojni dio prakse jer da bismo obavljali neku praksu uvijek nam trebaju „stvari“, i u povratnoj sprezi te stvari utječu na društvenu praksu, odnosno način njenog obavljanja (primjerice društvene online platforme mijenjaju i prakse praćenja medijskog sadržaja i prakse druženja).

Kao što Werron i Ringel (2020.: 56) primjećuju, „nesigurnosti i događajni karakter pandemije ukazuju na korisnost strategije istraživanja utemeljenog na (društvenim) praksama koje se fokusira na rutinirane aktivnosti koje su uspostavljene i reproducirane, izmijenjene, povezane, nepovezane, institucionalizirane, tijekom pandemije“. Život tijekom pandemije na neki je način u kratkom vremenu dao mogućnost razumijevanja i učenja o tome kako se društvene prakse stvaraju i mijenjaju. Autori uvode nov pojam „pandemijskih (društvenih) praksi“, praksi nastalih, održavanih ili promijenjenih tijekom pandemije. Definiraju ih kao „(1) društvene prakse koje se (2) pojavljuju i/ili mijenjaju tijekom pandemije COVID-19, koje su (3) povezane na neki način s otkrićem ili širenjem SARS-CoV-2 virusa i (4) mogu se međusobno povezivati tijekom pandemije COVID-19“ (str. 57). One su generirane tijekom pandemije, te na neki način čine virus stvarnim društvenim događajem. Autori predlažu tipologiju tih pandemijskih praksi i dijele ih na primarne, responzivne i adaptivne te dodaju četvrtu 
kategoriju takozvanih metapraksi, koje diskutiraju, uspoređuju i evaluiraju prethodno navedene tipove praksi i na taj način uvjetuju otpornost drugih pandemijskih praksi. Pritom su primarne pandemijske prakse one koje se direktno tiču i povezane su s definiranjem pandemije i upravljanjem njome kao društvenim problemom (dijeljenje epidemiološkog znanja u javnosti, klinička testiranja, otkriće i dijagnoza virusa, pokušaji sprečavanja širenja virusa te rješavanje povezanih simptoma i bolesti). To su, primjerice, testiranje na SARS-CoV-2, otvaranje odjela za liječenje pacijenata oboljelih od bolesti COVID-19, političke odluke o lockdownu i ponovnom otvaranju, dnevne tiskovne konferencije o pandemiji, mjere poput držanja fizičke distance, nošenja maski, propisivanja broja osoba koje mogu biti u nekom prostoru istovremeno, novi načini rukovanja itd. Odnosno, sve što direktno ima veze s virusom i širenjem (odnosno sprečavanjem širenja) virusa. Većina tih praksi direktno je ustanovljena putem javnih institucija koje su ih „nametnule“ i/ili promovirale. Responzivne su pandemijske prakse, prema Werronu i Ringelu (2020.), one koje izviru ili se multipliciraju tijekom pandemije kao instant odgovori na definiranje i rješavanje problema u primarnim pandemijskim praksama. To su, primjerice, online sastanci i predavanja putem platformi Zoom/Teams/Meet/Skype umjesto uživo, kreiranje nastave/prezentacija prigodnih za online platforme, naručivanje hrane i potrepština online, hrana i piće za van gdje to prije nije postojalo kao usluga ili poduzimanje dugih šetnji i planinarenja umjesto odlaska u teretanu. U mnogome te su prakse zamijenile dosadašnje društvene prakse (rad na radnom mjestu, poučavanje uživo, sastanci uživo, ručanje u restoranu, rekreacija u zatvorenim prostorima) koje trenutno zbog pandemije nije moguće prakticirati. I treće su takozvane adaptivne pandemijske prakse, nastanak kojih nije direktno povezan $s$ pandemijom i koje su postojale i prije, no uslijed novih uvjeta one se u malo izmijenjenim oblicima prakticiraju te i dodatno razvijaju. To su, primjerice, način kupovanja u dućanima i obilasci dućana s maskama i manji broj ljudi istovremeno, pandemijske mjere u sportskim objektima, u obrazovnim ustanovama, u kazalištima i kinima, javnim događanjima, na izborima, promjene u načinima provođenja svadbi, sprovoda, obiteljskih okupljanja i drugo. Radi se, dakle, o svim praksama koje su prilagođene novim uvjetima (a nisu zamijenjene drugim praksama) te stoga s njima indirektno imaju veze. Werron i Ringel (2020.) navode i četvrti tip praksi, koje nazivaju metapraksama. Te su prakse one koje na diskurzivnoj razini podupiru i čine trajnim ili kratkotrajnim druge pandemijske prakse. Odnose se uglavnom na izvještaje, dokumente, načine na koji različite institucije i drugi akteri javno oblikuju diskurs o pandemiji, njenoj historijskoj važnosti, najboljim uočenim pristupima i o budućnosti društva nakon pandemije. U našim analizama za primjećivanje i klasificiranje novih aspekata svakodnevnice žena najkorisniji nam je dio tipologije povezan s responzivnim $\mathrm{i}$ adaptivnim praksama.

U kontekstu pandemijskih društvenih praksi i naših nalaza važno je i pitanje takozvane sržne ekonomije, ili ekonomije brige, koja je povezana i s konceptima društvene pravde i kvalitete života, a koji izviru kao ključna pitanja u društvenoj krizi poput 
ove. Društvena dobrobit, jednakost i zadovoljenje osnovnih potreba u centru su razumijevanja društvene pravde, pri čemu dobrobit znači da ljudi funkcioniraju dobro, i privatno i društveno, uz osjećaj vlastite kompetentnosti, životnog smisla i svrhe, povezanosti s drugima (Michaelson i sur., 2009., Abdallah i sur., 2011.) te da mogu zadovoljiti vlastite fizičke i psihološke potrebe. Ukupna dobrobit (engl. wellbeing) ovisi o izvanjskim faktorima, kao što su dohodak, uvjeti stanovanja, stečeno obrazovanje, društvene veze i povezanost kao i o (povezanim) osobnim resursima, kao što su fizičko zdravlje i psihološka otpornost. No, osim navedenih izvanjskih i unutarnjih resursa, postoje i vrlo važni „nekomodificirani“ ljudski i društveni resursi koji su uključeni u život svakog pojedinca. Oni su ukorijenjeni u svakodnevnom životu, a to su, primjerice, mudrost, iskustvo, energija, znanje i vještine te u interpersonalnim vezama ljubav, empatija, odgovornost, reciprocitet, poučavanje, učenje od drugih i briga za druge. Budući da su ti resursi od središnjeg značenja za društvo, oni se nazivaju i sržnim za ekonomiju jer su predmetom individualne i društvene produkcije i razmjene (Coote, 2015.). Ta se vrst ekonomije proteže i puno dalje od obitelji i prijatelja, obuhvaćajući cijele proširene mreže, susjedstva, interesne zajednice. Ona je ključna za društvo jer na njoj počiva ekonomija, budući da o njoj ovisi odgoj djece, briga za bolesne, nemoćne ili osobe s invaliditetom, briga za prehranu obitelji, održavanje kućanstva te izgradnja i održavanje intimnosti, prijateljstva, društvenih veza i civilnog društva. Tu su još i praktične stvari poput učenja i poučavanja kuhanju, vrtlarenju, popravcima koječega što pomaže ljudima ne samo u osjećaju samosvrhovitosti već i u kvaliteti svakodnevnog života (Abdallah i Jeffrey, 2014.). To je, nažalost, i područje ekonomije u kojem se reproduciraju društvene nejednakosti, posebice one rodne. Kako je to neplaćeno vrijeme raspodijeljeno među ženama i muškarcima te među različitim društvenim grupama ima utjecaj na društvenu nejednakost i u ostalim domenama života (Coote i Franklin, 2013.; Goodwin, 2010.). S obzirom na prirodu mjera izolacije, koje su zatvorile kućanstva iza zidova vlastitog doma, vrlo je važno pitanje na koji se način to iskustvo odrazilo na ukupnu dobrobit kao i na ekonomiju brige te koliko je to utjecalo na povećanje društvenih nejednakosti.

Gore navedeni resursi važni su za otpornost, pri čemu neki autori definiraju otpornost kao kapacitet "prilagodbe postojećih resursa i vještina na nove situacije i uvjete odvijanja života" (Comfort, 1999.: 21), dok drugi nadodaju i pitanje budućeg funkcioniranja te kažu da se radi o "procesu povezivanja seta adaptivnih kapaciteta u pozitivnu putanju funkcioniranja i prilagodbe nakon poremećaja“ (Norris i sur., 2008.: 130). No, neke definicije idu i korak dalje te kažu da se radi o ,sposobnosti da se pripremi, planira, apsorbira i oporavi od ili uspješno prilagodi na aktualne ili potencijalne nepovoljne događaje" (National Research Council, 2012.: 1). Dakle, ne radi se samo o otpornosti na disrupciju već i o kapacitetu za adaptaciju i nakon disrupcije. Otpornost se, međutim, može mjeriti na različitim nivoima analize, individualnom, obiteljskom, nivou zajednice, općem društvenom nivou. Zbog prirode ovog istraživanja, koncept otpornosti važan nam je na osobnom i obiteljskom nivou. U literaturi pronalazimo da 
su za otpornost važni koncepti poput stanja dobrobiti prije disrupcije kao i socijalni kapital pojedinca, no i povezanost zajednice čije je pojedinac dio (npr. Aldrich, 2012., Comfort, 1999.). Za otpornost jedno je od ključnih pitanja i percepcija budućnosti. Mnogi autori smatraju kako su percepcije budućnosti od aktera važne u njihovim društvenim ishodima (Beckert i Suckert, 2020.). Pronađeno je da je mjera u kojoj akteri smatraju da mogu sami u pozitivnom smislu oblikovati svoju budućnost važna u razumijevanju i njihovih očekivanja i motivacije, odnosno kad akteri smatraju da je budućnost posljedica njihovih akcija, tada i „rezoniranje unatrag iz budućnosti“ postaje plauzibilno (Emirbayer i Mische, 1998.). Dok mnogi autori smatraju da je očekivanje od budućnosti važan dio identiteta osobe (Beckert i Suckert, 2020.), također je važno reći i da u očekivanjima od budućnosti postoje ključne društvene silnice, koje uokviruju osobne narative. Na temelju opisa izolacije naših sudionica istraživanja u ovome radu razmatramo životne okolnosti i misli, uključujući one o budućnosti, koje žene čine otpornijima u ovakvim izazovnim događajima.

To sve, kao i prije rečeno, otvara nam vrlo važnu klasnu perspektivu našeg rada. Naime, istraživanja u području sociologije katastrofa pokazuju da je sposobnost pripreme na katastrofu, smanjivanja njezinih negativnih posljedica i uspješnog oporavka od njih klasno pitanje i da ovisi o dostupnim resursima (Tierney, 2019.). U tom smislu neki autori koriste i prilagođavaju Bourdieuovo (1984.) razlikovanje ekonomskog, kulturnog i društvenog kapitala kao važne resurse za otpornost (npr. Uekusa, 2018.). Prema Bourdieu (1984.), kulturni kapital čine obrazovne kvalifikacije koje uživaju visoki status u društvu, legitimni ukus u kulturnim sadržajima, posjedovanje kulturnih dobara, dok se ekonomski kapital odnosi na materijalno bogatstvo sadržano, primjerice, u posjedovanju nekretnina ili primanjima. Društveni kapital pak čine stvarni ili potencijalni resursi dobiveni putem korisnih poznanstava i članstva u određenim grupama (Bourdieu, 1984.). U kontekstu pandemije, klasna se dimenzija do sada isticala vezano uz izloženost zdravstvenom riziku i ekonomsku ranjivost (prema Holst i sur. (2020.) pripadnici radničke klase u njihovom istraživanju u Njemačkoj iskazuju veći rizik oboljenja od koronavirusa i veće ekonomske rizike od pripadnika više klase; Collinson (2020.) zaključuje kako će ekonomske posljedice pandemijske krize biti teže za one koji obavljaju slabije plaćene poslove i koji ne mogu raditi od kuće), zatim vezano uz razlike u uvjetima stanovanja za vrijeme izolacije te vezano uz razlike u obrazovnim iskustvima djece pripadnika različitih klasa (npr. Bonal i Gonzalez, 2020.). Klasna dimenzija svakodnevnog života za vrijeme izolacije istaknula se i u našem istraživanju.

\section{Recentne korisne spoznaje o iskustvu života i pandemijskim praksama tijekom karantene uslijed pandemije COVID-19}

U preglednom radu o rezultatima 58 socioloških istraživanja o posljedicama koje pandemija koronavirusa ima na društvo, Grasso i suradnici (2021.) navode kako u jesen 2020. godine, za vrijeme dok se tek razvija drugi val infekcija, postaje jasno kako je kriza rezultirala ne samo u iznimnom gubitku ljudskih života, i različitih zdravstvenih 
oštećenja kod preživjelih, već i u nizu psiholoških, društvenih i ekonomskih posljedica u europskim društvima. To se posebice odnosi na žene, migrante, starije ljude, njegovatelje te beskućnike, skupine koje su posebice teško pogođene, što dodatno pojačava već postojeće društvene nejednakosti. Koliko god da je mobilizirala pojedince na solidarnije i drugačije ponašanje i odnošenje, toliko je povećala izolaciju pojedinih skupina društva te netrpeljivosti, van i unutar granica država. To je, primjerice, posebno vidljivo u međugeneracijskom okrivljavanju mladih da se ponašaju neobzirno i prenose virus na ranjive skupine, a starijih da su krivi za oštre mjere zatvaranja. Također, prisutna je stalna debata o srozavanju demokratskih vrijednosti i ljudskih i političkih prava tijekom pandemije, a ekonomska kriza već se pomalo nazire.

Za ovaj rad posebno su nam zanimljivi radovi koji su se bavili svakodnevnicom tijekom izolacije, s fokusom na rodne razlike. U komparativnoj studiji koja se temeljila na online istraživanjima tijekom pandemije u Njemačkoj i Italiji (Kulic i sur., 2020.), autori pronalaze da je pandemija dovela do razlike u distribuciji dohotka u kućanstvima, te da su češće bez dohotka ili sa smanjenim dohotkom ostajale žene i posljedično je njihov doprinos kućanskim poslovima još više porastao. U radu Fodora i suradnika (2020.), istraživanje u Mađarskoj pokazalo je da, iako je tijekom pandemije došlo do porasta sudjelovanja muškaraca u kućanskim poslovima, to je opterećenje poraslo i za žene, i to na način da umjesto da se raspodjela približi pravednoj, jaz je još više narastao, i to primarno među visokoobrazovanima. Kako pokazuje panel istraživanje u Njemačkoj, veliki je problem u njezi djece tijekom mjera zatvaranja. Ako i zadrže jednaku raspodjelu kućanskih poslova, najveći teret brige za djecu pada na žene, što rezultira u njihovoj smanjenoj mogućnosti obavljanja profesionalnih dužnosti i što se često nastavlja i nakon što mjere zatvaranja popuste (Hipp i Bunning, 2020.). To utječe na smanjenje zadovoljstva kvalitetom života kod žena. Istraživanja također pokazuju da je općenito došlo do smanjenja zadovoljstva partnera u vezama i smanjenja kvalitete veza te povećanja konflikata među partnerima u odnosu na predpandemijski period (Schmidt i sur., 2020.). Što se tiče preokupacije brigom, jedno njemačko istraživanje pokazuje da su žene uglavnom brinule o obitelji i djeci, a muškarci su uglavnom bili preokupirani poslom (Czymara, Langencamp i Cano, 2020.), no generalno smanjenje doživljaja dobrobiti i zadovoljstva obiteljskim životom opaženo je u većoj mjeri za majke no za očeve (Möhring i sur., 2020.). Također, vrlo je važan nalaz da je socijalna izolacija u jeku pandemije izazvala puno veće smanjenje zadovoljstva života i subjektivnog osjećaja dobrobiti kod žena nego kod muškaraca (Ohlbrecht i Jellen, 2020.). Žene koje obavljaju akademski posao, kako istraživanja pokazuju, puno su lošije prošle tijekom pandemije $\mathrm{u}$ odnosu na muškarce $\mathrm{u}$ akademskom poslu, smanjile su im se šanse za napredovanje i povećale za prekarnost zbog činjenice da su mogle manje pisati i objavljivati radove upravo kao posljedica većeg opsega kućanskih poslova i tereta povećane brige za djecu (Minello i sur., 2020.). Za kraj ovog kratkog pregleda, za nas je također vrlo zanimljivo talijansko kvalitativno istraživanje o iskustvu života tijekom pandemije u kontekstu rada od kuće (Risi, Pronzato i Di Fraia, 2020.). Rezultati tog 
istraživanja pokazuju da su građani morali nanovo osmisliti svoje svakodnevne prakse te redefinirati granice svojeg iskustva. Morali su se nositi s manjkom osobnog prostora, što je rezultiralo stresom i premorenošću te kolapsom uobičajenih granica između profesionalne i privatne sfere, što je dodatno zahtijevalo kompleksno upravljanje svakodnevnim aktivnostima.

Od korisnijih kvalitativnih uvida izdvojimo i da je u Poljskoj provedeno istraživanje koje je koristilo formu dnevnika tijekom karantene, a koji su građani slali kao prijavu na nagradni natječaj (Lukianow i sur., 2021.). U tom istraživanju sudjelovalo je znatno više žena (81\%) nego muškaraca (19\%). Autori su napravili taksonomiju dnevnika na terapeutske - koji se fokusiraju na ili promišljaju vlastite emocije i misli, spominjući emotivne krize, moguće terapijske motivacije i efekte; opisne - koji ukratko izvještavaju o većim događajima i novim restrikcijama, bez otkrivanja (ili s vrlo malo otkrivanja) osobnih iskustava; relacijske (odnosno relationship-driven) - koji se fokusiraju na odnose u zajednici (obitelj, lokalna zajednica, proširena obitelj); književne - koji su kao priče ili fikcija, uključujući poeziju; i one koji su fokusirani na roditeljstvo - fokusiraju se na poteškoće u roditeljstvu, npr. online nastava i zabavljanje djece tijekom izolacije. Ponešto dnevnika bilo je takozvanih patriotskih, koji su narativno prizivali zajednišstvo u „ratu“ nacije protiv virusa.

\section{0 istraživanju}

Ovo istraživanje u svojoj osnovi osmišljeno je kao odgovor na pitanje kako izgleda svakodnevnica hrvatskih građana tijekom lockdowna, odnosno izolacije radi zaustavljanja širenja epidemije bolesti COVID-19. Koje ih misli okupiraju i kojim se aktivnostima bave, kako se osjećaju, kako se njihov život promijenio tijekom ovog razdoblja te kakva su njihova razmišljanja o društvu i budućnosti. U periodu od 14. do 24. travnja 2020. godine provedeno je anonimno online istraživanje putem platforme Google Forms. Protokol namijenjen ispunjavanju sadržavao je pet tematskih cjelina:

- razmišljanja o pandemiji na različitim razinama (ja - neposredna okolina - šira okolina - svijet)

- $\quad$ svakodnevnica tijekom karantene, tipičan dan, misli i aktivnosti

- razmišljanja o budućnosti i refleksija o naučenom iz iskustva

- $\quad$ pomoć i podrška

- $\quad$ kvaliteta mjesta života

Pitanja su bila otvorenog tipa, poput: Za koje ključne riječi smatrate da dobro opisuju svijet ugrožen pandemijom? Kako izgleda Vaš tipičan dan otkada smo pod mjerama izolacije? Koje Vam sve misli i aktivnosti pomažu? Razmišljate li o svojoj budućnosti i ako da, o čemu? Na samom kraju prikupljeni su i sociodemografski podaci sudionika/ ca istraživanja uključujući spol, dob, stupanj obrazovanja, broj djece, radni status i zanimanje. 
Istraživanje je bilo anonimno, te nisu prikupljana imena i prezimena, e-mail adrese ili IP adrese sudionika/ca istraživanja. Pri samom početku protokola navedena je bila svrha istraživanja, tko provodi istraživanje i tko će imati pristup podacima. Obećale smo da ćemo podatke analizirati na način da neće biti moguće prepoznati tko je sudjelovao $\mathrm{u}$ istraživanju. Također je napomenuto da sudionici mogu u bilo kojem trenutku odustati od popunjavanja protokola ukoliko osjete frustraciju ili nelagodu zbog postavljenih pitanja.

U proceduru prikupljanja podataka krenule smo na nekoliko načina. Podijelile smo svojim kolegama i poznanicima poziv te ih zamolile da ga proslijede dalje. Objavile smo poveznicu na istraživanje i poziv na društvenim mrežama. U svojim smo ustanovama zamolile da podijele poziv na istraživanje na stranicama društvenih mreža i interno. U roku od deset dana u istraživanju je sudjelovalo ukupno 447 sudionika/ ca, od čega 393 žene. Takva situacija nalik je istraživanju u Poljskoj (Lukianow i sur., 2021.), u kojem je 83\% žena poslalo dnevnike tijekom izolacije, što autori podupiru nalazima Plant i sur. iz 2000. godine, koji navode da je češće sudjelovanje žena u otvorenom iznošenju emocija posljedica usvojenih rodnih uloga. Dodatno, 213 žena prema obrazovanju i zanimanju potpada $\mathrm{u}$, bourdieuovskim riječnikom, dominantnu klasu. Radi se o visokoobrazovanim ženama, koje su, primjerice, znanstvenice, odvjetnice, konzultantice, liječnice i terapeutkinje. Zbog načina prikupljanja podataka i dostupnih opcija provođenja istraživanja u trenutku trajanja karantene nismo mogle osigurati uzorak koji bismo željele, a koji bi bio klasno heterogeniji. Stoga, po završetku prikupljanja odgovora, zbog toga što su protokol ispunile uglavnom žene, u najvećoj mjeri visokoobrazovane, za ovaj smo se rad odlučile koncentrirati na njihovo iskustvo. Taj nam se pristup poduzorkovanja čini zanimljivim i iz razloga što na taj način možemo reći da govorimo o takozvanom neslučajnom (pod)uzorku kritičkih slučajeva, slučajeva koji nam mogu dati takav pogled na fenomen da možemo reći da ukoliko se nešto negativno tijekom karantene događa kod njih, vrlo je vjerojatno da se događa i drugdje (Patton, 2007.: 236-237). Odnosno, ono što je istinito i stvarno za žene iz viših klasa, frustracije, problemi, strahovi i pitanja koji se događaju kod njih, možemo očekivati da su još istaknutiji u klasama u kojima je ekonomska neizvjesnost veća i stoga budućnost složenija. Na taj način neka od iskustava i praksi možemo vidjeti kao tipične za žene iz našeg uzorka, a neka kao indikatore potencijalnih proširenijih događaja u nižim klasama.

U svjetlu navedenog, pitanje kojim se bavi rad jest: Kako su izolaciju, odnosno karantenu doživjele naše sugovornice? Ali iz teorijskog dijela bismo dodale: Koje pandemijske prakse možemo uočiti u iskazima naših sudionica te što možemo zaključiti o otpornosti naših sudionica i koju ulogu u tome imaju njihovi kapitali?

$U$ analizi smo koristile odgovore na prve tri tematske cjeline. U prvoj cjelini pitanja su: „Za koje ključne riječi smatrate da dobro opisuju svijet ugrožen pandemijom?“, „Navedite ključne riječi koje smatrate da dobro opisuju vašu obitelj i prijatelje tijekom 
pandemije?“, „Navedite ključne riječi koje smatrate da dobro opisuju Vas tijekom pandemije?“. U drugoj su cjelini pitanja opisa tipičnog/atipičnog dana: „Kako izgleda vaš tipičan dan otkad smo pod mjerama izolacije? Počevši od jutra do večeri? Kako izgleda atipičan?“, „Kako se razlikuje jedan vaš tipičan dan otkada smo pod mjerama izolacije od tipičnog dana prije mjera izolacije?" te pomažuće misli i aktivnosti tijekom izolacije: „Koje vam sve misli i aktivnosti pomažu u ovo vrijeme izolacije?“ U trećoj su cjelini razmišljanja o budućnosti: „Razmišljate li o svojoj budućnosti tijekom izolacije i ako da, o čemu vezano uz svoju budućnost?", „Razmišljate li o budućnosti vašeg grada, države, svijeta i ako da, o čemu vezano uz budućnost?" te refleksija na naučeno iz iskustva: „Smatrate li da ste tijekom izolacije nešto o sebi, drugima, društvu, životu naučili?".

Na prikupljenim podacima napravljena je tematska analiza. Radi se o višestrukoj rekurzivnoj analizi podataka (Braun i Clarke, 2006.), odnosno o šest etapa: (1) familijariziranje s podacima; (2) generiranje inicijalnih kodova; (3) povezivanje kodova u potencijalne teme, povezivanje podataka relevantnih za pojedine teme; (4) provjeravanje/revidiranje tema; stvaranje tematske mape analize; (5) definiranje i imenovanje tema (rafiniranje specifičnosti svake teme, generiranje jasnih definicija i imenovanje tema); (6) izvještavanje (završna prilika za analizu, odabir kodiranih isječaka za ilustraciju tema, konačna analiza s aspekta istraživačkih pitanja i literature).

U radu prikazujemo četiri teme koje su identificirane analizom: karantena kao kompleksno emotivno iskustvo, pandemijske prakse, pomagači u prilagodbi te izvorišta i učinci pandemije.

\section{Karantena kao kompleksno emotivno iskustvo}

Od početka pandemije otvaraju se pitanja o posljedicama pandemijske krize na psihičko zdravlje ljudi, pri čemu se naglašava povećani rizik od psihičkih oboljenja poput depresije i anksioznosti, a što ima i svoju rodnu dimenziju (npr. Delmastro i Zamariola, 2020.). U svojem smo istraživanju dobile uvid u emotivna stanja svojih sugovornica za vrijeme karantene kroz, primjerice, riječi koje sudionice spominju kao ključne riječi vezane uz svoje iskustvo pandemije, ali i njihove opisne rečenice. Na osnovi njihovih odgovora zaključujemo kako je iskustvo karantene bilo emotivno kompleksno i nesvodljivo na dihotomije isključivo negativnog ili isključivo pozitivnog pri čemu valja uzeti u obzir da se istraživanje provodilo za vrijeme prvog vala pandemije i da bi isto istraživanje danas moglo dovesti do drugačijih zaključaka.

U ključnim riječima o sebi koje su upisale naše sudionice istraživanja izmjenjuju se zabrinutost zbog pandemije s opuštenosti i optimizmom, strah za budućnost djece i unuka, ali i užitak u usporavanju života i bavljenju smirenim aktivnostima. Tako se, 
primjerice, u dobi mlađoj od 30 godina izmjenjuju i smirenost i opuštenost i zabrinutost. Jednako tako u kasnijoj životnoj dobi ključne su riječi izmiješane emocije: zabrinutost, discipliniranost, radišnost, opuštenost (s26, 51 - 60). Općenito se u toj kasnijoj dobi više ističe optimizam i smirenost, nada da će sve biti u redu. S druge strane, u dobi od 31 do 50 godina, kada žene uglavnom imaju mlađu djecu i ekonomski su najaktivnije, u ključnim riječima o sebi nailazimo učestalije na teške riječi poput iscrpljenosti, beznađa, zabrinutosti, bezvoljnosti, straha i stresa, ali spominje se i opuštenost. Sljedeći citat ilustrira taj mozaik emocija: Cijeli raspon emocija, od spokoja i opuštenosti do histerije, bijesa, agresiunosti, razočaranja, očaja (s1, $41-50)$.

Ključne riječi o obitelji i prijateljima također su emotivno obojene i čine se dobrom ilustracijom obiteljske i šire društvene dinamike tijekom izolacije. Zbunjenost, strah i iščekivanje izmjenjuju se s ljubavlju, toplinom, solidarnošću. Neke od žena spominju svađe i napetosti, neke „kabinsku groznicu“, druge zabrinutost za roditelje koje dugo nisu vidjele i kojima nedostaju unuci. Čekanje na druženja i pokušaji ostanka u kontaktu s prijateljima unatoč trenutnoj razdvojenosti dominiraju odgovorima u svim dobnim skupinama.

U vezi mentalnog zdravlja i otpornosti, čini se da zaokupljenost svakodnevnicom i strukturiranjem dana kod žena koje imaju djecu daje puno manje prostora za trenutne krize u vlastitom mentalnom zdravlju, a nema vremena ni za bezvoljnost i poteškoće $s$ ustajanjem iz kreveta. Samo za premorenost i u tipičnim i netipičnim danima. Žene bez djece ili sa starijom djecom pak nalaze dobre strane u izolaciji, u opuštanju i usporavanju života. Kao da vrijeme teče drugačije, kako primjećuje jedna od sudionica: Generalno, imam više vremena $i$ manje obaveza pa mi je sad dan kvalitetniji. (s50, 31 - 40), također: Lakše je jer nikud ujutro ne žurimo. Ne žurimo na aktivnosti, ne gubimo vrijeme u prometu... (s14, 41 - 50) te također: Razlikuje se u kvaliteti života - duže spavam, višse odmaram, više se bavim stvarima koje volim $i$ nisam ni malo izložena stresu. $(s 27,41-50)$. S druge strane neke žene, posebice mlađe od 30 godina, imaju dane koje cijele provedu u krevetu, imaju psihičke poteškoće i osjećaju potpunu bezvoljnost. No, to opisuju uglavnom kad opisuju atipične dane, što znači da većinu vremena nekako drže glavu iznad vode.

Atipičan: ne mogu se ustati, jedva se izvlačim iz kreveta, obrok, eventualna prisila na nekakav rad (produktivnost nula), izbjegavanje obaveza, smirivanje vlastitih misli, razgovor s bliskim ljudima, distrakcije (čitanje, igrice, ljubimci, izlazak u šetnju), izrazita tjeskoba i bezvoljnost. (s31, $20-30)$

Atipičan je dan kada se ne osjećam dobro / lošeg sam raspoloženja i nemotivirana tada se pokušavam natjerati da napravim bar dio od stvari s tog popisa. (s18, 20 - 30) 
Za razliku od iskaza vezanih za sebe, obitelj i prijatelje, u kojima se isprepliću i pozitivne i negativne emocije, ključne su riječi o svijetu pesimističnije. Slika svijeta iz izolacije potiče žene da kao ključnu riječ koriste strah. Strah je riječ koja se najčešće spominje i gotovo su je sve žene upotrijebile. Radi se o strahu od smrti, od neizvjesnosti, od nepoznatog, od bolesti, o strahu od gubitka dragih osoba, strahu od drugih ljudi. Nakon straha često se spominju neizvjesnost i tjeskoba te mnoge žene opisuju sentiment nalik ovome:

[T]jeskoba, neizvjesnost, strah - zbog brzine i nepredvidivosti sirenja virusa, neizvjesnost o mogućnosti povratka u normalu, strah zbog osjećaja prijetnje i opasnosti. (s43, $41-50)$

Prekid. Gubitak. Neizvjesnost. Prekid dosadašnjeg života, gubitak lijepih navika, kontakta s prirodom $i$ drugim ljudima. Neizvjesnost kamo nas sve ovo vodi $i d a l i$ predstoji život bez slobode. (s2, $41-50)$

U odgovorima se više puta spominjao prekid normalnog života, neizvjesnost zbog promijenjene svakodnevnice, zbog izolacije od drugih. Neizvjesnost podcrtava pitanje kamo sve to vodi, kako će se sve završiti, u kakvoj vrsti društvene budućnosti. Govori se o prekidu, pauzi, sve je stalo. Također, ali sporadično, i briga zbog gubitka slobode.

Vezano uz brigu, kada sudionice razmišljaju o svojoj budućnosti, dominantno ih brinu ekonomske posljedice pandemijske krize. Odgovori nekih od njih sugeriraju s jedne strane financijsku udobnost, a s druge zabrinutost da će se ona promijeniti uslijed gubitka posla ili smanjivanja plaće:

U manjoj mjeri razmišljam o bližoj budućnosti i ekonomskoj situaciji koja me očekuje ukoliko mi se smanje primanja. (s3, $41-50)$

Najviše razmišljam o tome hoću li imati novaca za stvari koje su i prije izolacije bile svojevrsni luksuz, terapija, trening za pse, organska hrana, potom hoću li zadržati posao ili ću dobiti otkaz, kako ću u tom slučaju moći plaćati kredit. (s12, 31 - 40)

Hoću li ostati bez posla? Što ću tada raditi? (s9, 31 - 40)

Iz odgovora sudionica zaključujemo da je pandemijska kriza iskustvo uokvireno različitim emocijama, i pozitivnim i negativnim, i smirenosti i opuštenosti, ali i strahom i brigom, a što se uklapa u literaturu o katastrofama koja im pristupa kompleksno prepoznajući da su katastrofe i prilike za napredak na osobnoj i društvenoj razini (npr. Brundiers, 2018.). Ipak, neki uvidi iz našeg istraživanja pokazuju i da postoje sudionice kod kojih dominiraju negativne emocije, a što je važno za istaknuti s obzirom na podršku koju to zaziva. 


\section{Pandemijske prakse}

U prethodnom je dijelu istaknuto kako se u odgovorima naših sugovornica u više navrata spominjao prekid „normalnog “ života uslijed karantene. Što je to sve uključivalo za naše sugovornice? Iz njihovih je odgovora razvidno da je izolacija obrnula društvene prakse na način da ono što je prije bilo uobičajeno - druženje s prijateljima, odlazak u dućan, obavljanje sitnih zadataka kao što je odlazak u poštu, banku, odlazak u park s djecom pa čak i odlazak na posao - postaje atipično. Responzivne su prakse stoga značajno obilježile svakodnevnicu, od rada online, šopinga online, druženja online, vježbanja online, dugačkih šetnji do intenzivne pomoći u obrazovanju djece. U odgovorima sudionice spominju i strah od trajnije promjene društvenih praksi, restrikcija i nakon izolacije, a posebice od zatvaranja granica i teškoća u putovanjima: Najviše me muči mogućnost da nećemo moći na more (s4, 51 - 60).

Pandemijske prakse uključivale su rad od kuće, vježbanje kod kuće kao i različita usavršavanja poput satova stranog jezika ili kuhanja.

Ustanem malo kasnije nego što bih ustala da fizički idem na posao (spavam umjesto da putujem), krenem s radnim danom s početkom radnog vremena $u 9$ sati, provjerim emailove i radim uz povremene distrakcije koje uključuju čitanje članaka i slično, formalno završim s poslom u $17 \mathrm{~h}$, malo vježbam, povremeno se čujem s prijateljima, pohadam online kurseve ili držim savjetovanje, čitam, navečer se družim s mužem, idem spavati oko 1. (s30, 20 - 30)

Svakodnevne prakse izgledaju ponešto drugačije za žene $s$ djecom, a posebno za one $s$ djecom mlađom od šest godina. Tu primjećujemo rodni jaz u obavljanju kućanskih poslova i brizi za djecu: dojam je da je puno toga na ženama. U tom smislu responzivna pandemijska praksa žena u izolaciji s malom djecom jest preuzimanje uloge svemoćne žene. Ženama koje imaju malu djecu dani se svode na strukturu aktivnosti oko djece i s djecom, kako kratko navodi jedna sudionica: Buđenje, kava, doručak, djeca, posao, djeca, posao, ručak, djeca, posao, djeca, posao, večera, djeca, djeca, odmor (s59, 31 40). One balansiraju djecu, kućanske poslove i posao. Sljedeći citat to zorno ilustrira:

Ustajanje, doručak, davanje doručka djeci, igra s djecom, vika na djecu da budu tiši jer moram raditi, svada sa suprugom jer on radi u drugoj sobi i tu i tamo se pojavi u boravku, brisanje guza jer su išli na wc, netko od djece opet traži jesti, pranje rublja, vješanje rublja, izlazak s djecom na dvorište, boravak s djecom na zraku, vraćanje u stan, ručak, molim djecu da zaspu jer moram raditi, radim dok djeca spavaju, pijem kavu u tišini, djeca se bude, dajem im obrok (naravno da traže nešto drugo, a ne ono što je bilo za ručak), ukazivanje muža, odlazak van s djecom, kupanje, molim djecu da zaspu da se mogu odmoriti. Takav je tipičan i atipičan dan. (s66, 31 - 40) 
Učestalo je istaknuta emotivna briga, emotivni rad, podrška koju žene pružaju svojim ukućanima, djeci i suprugu kao i domišljanje što i kako s djecom, kako im popuniti vrijeme kvalitetno, kako se i zabaviti uz sve obaveze.

Tipičan: spremi doručak, počisti, igraj se s djecom, budi online za svoj posao, spremi ručak, počisti, prošetaj dijete ispred zgrade u kolicima da zaspe, provjeri je l' školarac izvršio sve zadaće, pomozi mu oko projekta, pričaj s mužem, reci im da ih voliš, obožavaš. Spremi večeru, počisti, ispeglaj, upali mašine za pranje, provjeri jesu li svi čisti, opranih zuba. Reci im opet svima da ih voliš i budi zahvalna sto imaš obitelj koju imaš. Ljubi ih, našali se s njima. Mnogo ih grli. (s5, 41 - 50)

Sudionice koje imaju djecu do šest godina starosti često izjavljuju kako nemaju atipične dane. Netipično u danima obično je odlazak u dućan ili u šetnju, do ureda ili pošte te pomoć starijim roditeljima i druženje s užom obitelji, dakle ne vrijeme za sebe nego za druge. Jer kako neke od njih primjećuju, u odnosu na razdoblje prije pandemije: sad nemam nimalo slobodnog vremena $(s 72,31-40)$. Ženama s djecom život se promijenio na način da nema prave razlike između privatnog i poslovnog, sve se stopilo u cjelinu bez jasnih granica. Naročito zato što vikendom često odrađuju posao koji nisu stigle odraditi tijekom tjedna zbog stalnih prekida i obaveza oko obitelji i djece. Također neke smeta što nema putovanja na posao, jasno odvojenog prostora i vremena za posao i osjećajnog i fizičkog.

Rad od kuće mi teško pada jer ne mogu fokusirano i bez prekidanja odraditi svoje radne zadatke. Smeta mi što mi se radno okruženje ne razlikuje od kućnog okruženja $i$ kada dode vikend nemam odmak od posla. Prije sam odradila posao i došla kucii, a ovako mi se posao prolongira sobzirom na obveze koje imam oko djece. (s56, 31 - 40).

Što se tiče praksi žena u pedesetima, čija su djeca starija ili nemaju djecu, one opisuju također vrlo strukturirane dane, no mnogo se manje spominju kućanski poslovi, više šetnje s prijateljicama te u mnogoj većoj mjeri prakse koje možemo smatrati indikatorima visokog kulturnog kapitala. Tako se u strukturi dana spominju hobiji poput online joge te online kazalište. Učestalo je čitanje knjiga te gledanje online filmova i serija. Te potonje dvije aktivnosti dosta su tipične za sve žene svih dobi, izuzevši majke male djece.

Pojedine žene svih dobnih skupina, ali posebice one sa starijom djecom ili bez djece, opisuju često i užitke povezane s novom svakodnevnicom, novim responzivnim praksama koje možemo opisati kao iznenadno usporavanje života, s puno većim razdobljima za odmor i uživanje. Neke žene uživaju i u činjenici da nisu u uredu, mnoge u tome da duže spavaju i u miru doručkuju, vježbaju, piju kavu. U dobi nakon 60 godina naviše život je čini se još sporiji, više je radova oko kuće, primjerice, a neke su žene i u ovom razdoblju u kući za odmor. Kako navodi jedna od sudionica: pijem kavu na terasi $i$ upijam sunce (s4, 61 i više). 


\section{Pomagači u prilagodbi}

U analizi odgovora primjećujemo da ono što ženama pomaže u prilagodbi na situaciju i omogućuje osjećaje zahvalnosti pa i sreće te su temelj za osjećaj solidarnosti jesu različite vrste kapitala. Oni prije svega zahvaćaju dobre materijalne uvjete, zatim kvalitetne odnose s drugima, kao i izloženost kulturnim sadržajima te usvajanje novih znanja i vještina. Ne manje važno, tu je uključeno i dobro zdravlje kako same sudionice tako i njezine obitelji. Važno je napomenuti da su neke sudionice u istraživanju isticale da su svjesne svoje privilegirane pozicije i na njoj su zahvalne.

Sreća, umreženost, povlaštenost. Moja obitelj i prijatelji se nalaze u relativno povlaštenom položaju jer imaju relativno stabilne materijalne uvjete, a svi su na neki način obiteljski, tj. socijalno umreženi što ublažava utjecaj pandemije. Nitko iz užeg ili sireg kruga poznanstva nije obolio. (s50, $31-40)$

Misli: pozitivne, ohrabrujuće. Planiranje nečeg konstruktivnog kada sve prode. Spoznaja da su djeca dobro, da se zdravo hranimo, da nismo u toliko lošoj situaciji kao netko tko je zarobljen u nekom stančiću u neboderu. Aktivnosti: šetnja šumom, sadnja biljaka oko kuce, yoga, duhovne aktivnosti, šaljive poruke na internetu, dobri odnosi s ukućanima. (s38, $41-50)$

Što se tiče aktivnosti koje ženama pomažu tijekom izolacije, žene bez mlađe djece su fokusirane na aktivnosti koje povezujemo $s$ višim kulturnim kapitalom: crtanjem, slikanjem, sviranjem, meditiranjem, jogom, odlascima na psihoterapije. Što se tiče misli koje im pomažu u kriznoj situaciji, u većoj mjeri su fokusirane na pozitivne aspekte izolacije: nikad se nisam bolje odmorila, nikad se nisam toliko posvetila bližnjima, radim ono što volim, imam vremena za hobije. Više mlađih sudionica razumjele su karantenu kao vrijeme za sebe, za razmišljanje o svom životu te o budućnosti, o tome da će ići na more i da će ovo proći i da će nešto iz ovoga naučiti.

Kod žena koje imaju djecu, misli i aktivnosti koje pomažu ponešto su drugačije. Izražava se zahvalnost za dobre materijalne uvjete i svjesnost privilegirane klasne pozicije, za to da su ona i njena obitelj na sigurnom, da imaju poslove, da provode tu izolaciju koliko-toliko pristojno i ugodno, „za mala zadovoljstva“. Dosta je razmišljanja o budućnosti, pozitivnih misli i planiranja budućih putovanja i odmora, što ukazuje na ekonomsku stabilnost. Žene kad stignu čitaju, igraju se s djecom, one bez djece ili sa starijom djecom vježbaju, druže se s prijateljima, a neke napominju da im pomaže i što puno rade ili su pak otkrile da mogu drugačije kuhati ili nešto raditi na drugačiji način.

Vizualiziram ljeto i putovanja. Odlazak u prirodu, razgovori s obitelji i prijateljima, kulturni sadržaji, glazba i ponešto alkohola pomažu. (s22, 41 - 50) 
Veselim se budućnosti i svemu sto se nadam da će opet biti moguće, dozvoljeno i dostupno; druženja i šetnje s frendicama, fina kava u kaficu, odlazak u grad, na plac, odlazak na more... (s3, $51-60)$

Navedeni citati ilustriraju nam važnost stabilnih materijalnih uvjeta, kvalitetnih osobnih veza i hobija kao pomagača za nošenje s kriznom situacijom. Sljedeći citat dodatno poentira važnost materijalnih uvjeta:

Zahvalna sam što živim u uvjetima u kojima nisam direktno ugrožena (imam dovoljno vlastitog prostora, vlastitih sredstava za život), ali brinem što već sada ima i bit će još više ljudi koji jesu ugroženi, i zdravstveno i egzistencijalno. Suosjećam s njima, pokušavam donirati koliko mogu, širiti pozitivnu energiju kad god mogu, iako ne vjerujem da je sve to dovoljno. (s16, 51-60)

Zanimljivo je da kod žena starijih dobi nema toliko referenci na budućnost ni buduće planove, više se drže sadašnjosti i zanimacijom u trenutnoj situaciji.

Čitam beletristiku i nađem na internetu što govore neke pametni ljudi kojima vjerujem i čijem mozgu se divim, šetnja sa psom i povremeni kratki susreti na daljinu s prijateljima. A misli zaustavim kad vidim da idu ka distopiji. Uglavnom, kad sam skoncentrirana na ovdje i sada, na samu sebe i krug meni bliskih ljudi osjećam se dobro. (s24, 51-60)

Jednako tako, neke sudionice starije dobi napominju da su stigle napraviti nešto čime se prije nisu mogle detaljno baviti, osobnim arhivama, pospremanjem i detaljnim čišćenjem pa i promjenama u stanu. No, fokusirane su na sadašnjost, zahvalnost zbog dobrih uvjeta života i uvjerenje da će sve ovo proći.

Uvijek sam bila optimist. Znam da ima ljudi koji su živjeli puno gore i prije ove pan-

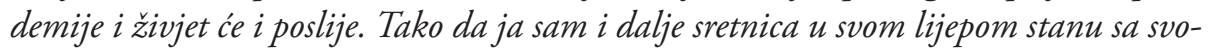
jim cvijećem na prozoru i svojom djecom koju mogu čuti kad hoću. Živim. (s3, 61+)

Izgleda da dobri materijalni uvjeti, odnosi s drugima i kulturne prakse daju i neizvjesnosti određeni šarm u smislu potencijala za nove vrijednosti i nove poglede na život, redefiniranja vlastite životne neizvjesnosti kao nečeg od manjeg značaja u odnosu na sve drugo, puno važnije.

Prihvatila sam situaciju i neizvjesnost, možda po prvi put u životu, zato što je sada to više od floskule koju inače izgovaramo - sada je situacija zaista neizvjesna kao što je i život kao takav UVIJEK neizvjestan. Shvatila sam koje su mi stvari zaista bitne - nisam opterééna gubitkom posla kojim svako ljeto popunjavam budžet i koji mi dopusta da ostatak godine funkcioniram kao freelancer bez pretjeranog egzistencijalnog straha; nisam opterecena gubitkom novca koji sam uplatila na propala putovanja $i$ 
festivale - kada razmišljam o povratku u "normalu" - ne razmišljam o materijalnom, već o zagrljaju, kavi na suncu, druženju uz čašu vina, uživanju u gužvi na nekom otvorenom koncertu. I zato sam sretna, jer negdje duboko u sebi osjećam da, dokle god su mi takve "sitnice" važne, stvari se mogu jednom u budućnosti vratiti na svoje mjesto $i$ da je izgledna mogućnost normalnog, toplog, solidarnog $i$ ispunjenog života nakon svega ovoga. $(\mathrm{s} 8,31-40)$.

\section{Izvorišta i mogući učinci krize}

Sudionice su u svojim odgovorima indicirale i što misle da su izvorišta krize te što smatraju da će biti posljedice. Kritički se spominje „razotkrivanje“ društvene stvarnosti, kako je pandemija dovela do razumijevanja koliko su ljudske slobode i društva krhka, nesigurna, kako je stabilnost ekonomije prividna i kako su društvene nejednakosti toksične.

U odgovorima naših sudionica vezano uz učinke krize dominira diskurs o nezaobilaznoj gospodarskoj krizi, gospodarskom slomu i katastrofi. Sudionice izražavaju brigu oko očekivane recesije, pri čemu neke od njih kao izvorište takve krize okrivljuju kapitalizam, a spominje se i pretjerano oslanjanje hrvatske ekonomije na turizam. Sljedeći citati u fokus stavljaju krhkost ekonomskog sustava i produbljivanje nejednakosti kao učinke pandemijske krize:

Čini se kao da je zdravstvena kriza ukazala na krhkost ekonomskog sustava koji uvelike ovisi o uvozu i izvozu, ulaganjima u transport, turizam, dobavljanje dijelova za ključne proizvode iz Azije i drugih dijelova svijeta, što s rastućom panikom oko širenja virusa ili više nije moguće ili je uvelike otežano zatvaranjem granica. To naravno dalje dovodi do zatvaranja mnogih poslova, do nove ekonomske krize, otpuštanja i štednje. Dodatno, čini se da će ova kriza više nego neke prije pokazati koliko je bogatstvo nagomilano u rukama nekolicine i kako će se više nego ikada prije vidjeti ogromne ekonomske razlike između onih koji ovise o poslovima u uslužnim djelatnostima i sličnim granama i koji žive isključivo od plaće koju primaju za svoj rad i onih koji imaju ranije akumulirano bogatstvo. (s43, $31-40)$

[I] medu pojedinim zemljama i unutar pojedinih drustava pandemija produbljuje već postojeće razlike. Ako sam virus ne pravi preveliku razliku izmedu bogatih i siromašnih, dugoročne posljedice sasvim sigurno će više pogoditi siromašne. (s16, 51 - 60)

Pored postojećeg ekonomskog sustava, antropo-kritičarke među našim sudionicama pandemijsku krizu vide i kao rezultat čovjekove sebičnosti i egoizma: 
Karma, bahatost, kapitalizam, glupost, sebičnost. Obrazloženje: bez navedenog imali bi znatno drugačiju sliku svijeta $i$ sebe samih u tom svijetu. Ova pandemija je samo kap u moru upozorenja ljudskoj rasi da se trgne. Ali neće. Jer novac će i dalje biti prioritet, a ljudska glupost, sebičnost, egoizam ne poznaju granice. (s5, 41 - 50)

Iako negativne posljedice na ekonomiju dominiraju u odgovorima naših sudionica, spominju se i druge moguće, zabrinjavajuće posljedice pandemije, uključujući ograničene ljudske slobode i veći nadzor ljudi od vlasti. To je dramatično sadržano u iskazu: [u]bijanje i ušutkavanje neistomišljenika (s2, 20 - 30), a ugrožene slobode naznačene su i u sljedećim citatima:

Vlasti će nas više kontrolirati. (s3, $31-40)$

[H]oće li restriktivne mjere uopće biti sasvim povučene ili ćemo „iz navike“ pri nekim stvarima ostati? $(\mathrm{s} 1,51-60)$

Među mogućim negativnim posljedicama pandemijske krize spominju se i međuljudski odnosi i otuđenje među ljudima: ljudi će se manje družiti i komunicirati in real life $(s 3,41-50)$.

Ranije smo spomenule da se u literaturi o katastrofama autori dotiču i pozitivnih aspekata kriznih situacija. U odgovorima naših sudionica ti se mogući pozitivni učinci pandemijske krize odnose u prvom redu na okoliš i općenito održiviji način života naspram fokusa na potrošnju i materijalno.

Nadam se da će se ljudi probuditi i prestati konzumirati više nego što im treba, usprkos kapitalizmu, početi više razmišljati svojim glavama, osjetiti poštovanje i povezanost s prirodom, njegovati prirodu $i$ zahvalnost na svemu što imamo. (s1, 31 - 40)

[O]čekujem da će se većina država okrenuti socijalizmu u smislu uspostavljanja javnog zdravstva koje nisu imali i da će održivi razvoj dobiti na većem značenju, da će se vrijednosti presložiti - od konzumerizma prema okrenutosti prema prirodi - nadam se. $(\mathrm{s} 4,41$ - 50)

Kako bi bilo lijepo da bar nešto dobro izađe iz ovoga, npr. da kapitalistički neoliberalni poredak (koji sad djeluje nesposobno da pruži bilo kakvu podršku u širem smislu) skroz propadne, $i$ da mora da se u nekoj mjeri vrati socijalna jednakost. To bi bilo lijepo. $(s 4,51-60)$

Kao moguće pozitivne posljedice spominju se i veća pravednost u svijetu, poboljšanje javnih usluga, posebice zdravstva, kao i solidarnije djelovanje i povezivanje ljudi. 


\section{Diskusija i zaključak}

Ukupno govoreći, kada bismo razmišljale o odgovorima sudionica u kontekstu nalaza do sada provedenih istraživanja, možemo reći da dominiraju opisi koji bi prema radu o pandemijskim dnevnicima Lukianow i sur. (2021.) spadali u terapeutske, koji se fokusiraju ili promišljaju vlastite emocije i misli, te na roditeljske, koji se bave poteškoćama u roditeljstvu tijekom izolacije. Tu su također i relacijski opisi jer se spominju odnosi u vezama, prijateljstva, briga za starije roditelje.

Kao i u spomenutom poljskom istraživanju, ali u drugačijoj ispovjednoj formi od naše, žene su se posebice u ključnim riječima o sebi fokusirale na vlastite emocije i misli, emotivne krize te moguće terapije u vidu hrabrenja, pozitivnih misli i drugih oblika samopomoći - skretanja misli, rada, okretanja k rutini. Njihov je emotivni život za vrijeme izolacije kompleksan te se isprepleću pozitivne i negativne emocije. Iz ispovijesti o tipičnim danima tijekom izolacije doznajemo da su žene s djecom zapravo u poziciji stupa obitelji, moraju biti snažne, teret brige za djecu je u većoj mjeri na njima. Ta im uloga ne ostavlja vremena za veće emotivne krize, bezvoljnost, depresiju, a koje iskazuju neke sudionice koje nemaju djecu. Postavlja se pitanje koje su dugoročne posljedice za te žene nakon što jednom prestanu zadržavati dah i raditi poput robota tijekom krize.

Naše sudionice dominantno opisuju rutinirani svakodnevni život obilježen responzivnim pandemijskim praksama. Tako, primjerice, dominira rad od kuće online. Zanimljiva je ta brza uspostava novih društvenih praksi u smislu njihove efikasne rutiniranosti i discipline oko njihova provođenja. Pomalo podsjeća na ratno stanje, ili stanje emotivne krize, u kojoj rutina daje odmor od stvarnosti kao što i postaje način preživljavanja. Ta praksa nekima je lakša, nekima teža, žene s malom djecom puno teže prihvaćaju takav način rada od žena koje nemaju djecu ili su im djeca starija, a koje često i uživaju u tom dobitku na vremenu da ne moraju putovati na posao, mogu duže spavati i sve je ukupno sporije. To usporavanje života teško je osjetiti ženama koje imaju djecu u kućanstvu na brizi jer osim izrazite potrebe za strukturiranošću i isprogramiranošću života, imaju također i poteškoće u obavljanju posla u nekom komadu normalnog radnog vremena, pa često opisuju kako rade navečer i vikendom. Ta iskustva koja žene opisuju podsjećaju na nalaze talijanskog kvalitativnog istraživanja o iskustvu života tijekom pandemije u kontekstu rada od kuće (Risi i sur., 2020.), koje je pokazalo da rad od kuće zbog kolapsa uobičajenih granica između profesionalne i privatne sfere može uzrokovati stres i premorenost te zahtijeva kompleksno upravljanje svakodnevnim aktivnostima.

Iz rezultata našeg istraživanja razvidno je da je izolacija doprinijela još većoj opterećenosti žena kako kućanskim poslovima tako i brigom za djecu. Njihov je rad također i emotivni rad, te naročito u dobi kad su djeca malena vrijeme izolacije jest vrijeme preopterećenosti, premorenosti i brisanja granica između poslovnog i privatnog zbog 
teškoća u ostvarivanju granica u vremenu koje je potrebno provesti s obitelji i u kojem je potrebno odraditi posao online. $U$ tom smislu, naš nalaz podupire zaključak Fodora i suradnika (2020.), koji su pronašli da se u Mađarskoj opterećenje u privatnoj sferi povećalo za žene, čime su rodne nejednakosti postale još izraženije. Naši nalazi podupiru i uvide Hippa i Bunninga (2020.), prema kojima je u Njemačkoj poraslo opterećenje žena brigom o djeci. Iz tih nalaza jasno je da ono što nazivamo sržnom ekonomijom, ekonomijom brige ključnom za održanje društva (Coote, 2015.) u slučaju zatvaranja institucija koje se brigom bave, pada u najvećoj mjeri na žene. Pandemijska kriza otkriva koliko su rodne nejednakosti i inače izrazite, te zapravo samo djelomično potisnute ili odgođene postojanjem institucija koje dio dana u uobičajenoj situaciji preuzimaju brigu za djecu (vrtići, škole). Time je osvijetljeno vrlo važno neriješeno i zapravo osjetljivo pitanje koliko je nuklearna obitelj, koja je u kapitalizmu prilično nemobilna, zatvorena u sebe, a koja stvara hipereksploatirajuću situaciju za zaposlene žene s djecom, zapravo dobra institucija i u smislu rodne ravnopravnosti kao i društvenog dobra, posebice iz aspekta ekonomije brige (McIntosh i Barret, 1982.). U izolaciji tijekom pandemije to pitanje postaje izraženije i u kontekstu opisanog pomaka ka sve većoj emotivnoj dinamici i angažmanu, ulaganju u odnose u obitelji kao i sve većoj količini introspekcije i samosvjesnosti unutar obitelji u kapitalističkom društvu (Zaretsky, 1986.), koja onda poprima enormne razmjere u situaciji potpune cjelodnevne izolacije obitelji.

Naposljetku, u sklopu pandemijskih praksi također se spominju šetnje i online vježbanja, online druženja s prijateljima kao i gledanje online kazališnih predstava. Dodatno, od adaptivnih praksi primjećujemo da neke žene ponovo uživaju u kuhanju i u eksperimentiranju u kuhanju za obitelj te domišljaju načine kako će provesti dane u kući s djecom, stvarajući razne vrste zabava ili uspostavljajući već zaboravljene načine zabave.

U pogledu otpornosti koja proizlazi iz određenih emotivnih stanja i misli, žene izražavaju raznolike emocije. Najmanje se otpornima u tom smislu čine najmlađe žene iz našeg uzorka, one u dobi do 30 godina, koje najviše pokazuju poteškoće povezane s mentalnim zdravljem i održanjem dobrog raspoloženja tijekom izolacije. Žene u dobi kada su obitelji mlađe, djeca malena do srednje velika, otpornost tijekom pandemije grade na zahvalnosti, ali i vrlo učestalo razmišljanju o u pravilu lijepoj budućnosti, svemu lijepom što će slijediti nakon ovoga, svemu što će napraviti kada sve ovo prođe. S druge strane, neke žene starije dobi gotovo da ne govore o budućnosti kada razmišljaju o tome koje im misli pomažu. One se primarno fokusiraju na to da je sve prolazno i da treba izdržati jer će i ovo proći. Umjesto na misli o budućnosti, one se oslanjaju na misli o povoljnoj sadašnjosti, koja je doživjela neku manju disrupciju koja će proći.

Pored određenih emotivnih stanja i misli koje doprinose otpornosti, uključujući i neki optimizam i nadu, pokazuje se jedna vrlo važna dimenzija otpornosti ovih žena, a koja je klasno uvjetovana. Naime, postoje objektivni čimbenici, kapitali (Bourdieu 1984.), 
koji ih čine otpornima, ili barem omogućuju lakšu prilagodbu, a to su ekonomski resursi: imati posao i zadovoljavajuća primanja, kvalitetno stanovanje; društveni resursi: kvalitetni odnosi s drugima, solidarnost (neformalna i formalizirana) te kulturni resursi: znanja i vještine potrebne za samoodrživost, dispozicija prema i mogućnost uživanja u kulturnim sadržajima i drugim slobodnim aktivnostima. Za razliku od tzv. herojske otpornosti, koja taj proces individualizira, primjećivanje uloge kapitala ilustrira i strukturne preduvjete otpornosti.

U pogledu određenih unutarklasnih razlika u iskustvu izolacije, među ženama je zapravo najizraženija razlika povezana s njihovom dobi i imanjem djece. Dobni kontekst posebno u smislu toga koliko su djeca malena ili velika te koliko opterećenje brigom predstavljaju čini ključnu razliku u iskustvu izolacije. Jer sva druga iskustva koja su vezana uz slobodno vrijeme, koliko god ga puno ili malo imaju, upućuju upravo na navike povezane s višom razinom kulturnog kapitala koje za njih čine život kvalitetnijim, a to su čitanje, bavljenje hobijima poput vježbanja joge, učenje dodatnih vještina te konzumiranje kulturnih sadržaja. Druge unutarklasne nijanse čine zabrinutost zbog budućnosti zaposlenja ili pak zbog problema sa stanom izazvanih potresom.

Što se tiče izvorišta i mogućih učinaka pandemije, u odgovorima sudionica pronalazimo kritiku kapitalizma i ljudske prirode, zabrinutost za moguće negativne posljedice pandemije poput ekonomske krize, produbljivanja nejednakosti, ograničavanja ljudskih sloboda kao i otuđenja među ljudima. S druge strane, pronalazimo i nadu da će pandemija dovesti do novog poretka koji će biti pravedniji, veće solidarnosti i posebno naglašenog boljeg odnosa prema prirodi. U tom smislu, glasovi ovih žena ne uklapaju se u dominantan medijski narativ o situaciji s pandemijom jer se navodi briga za starije, siromašnije, jasna je kritika antropocentrizma i čovjekovog uništenja prirode i s time povezana briga oko klimatskih promjena. Naše sudionice pokazuju društvenu osjetljivost i želju za društvenom promjenom, a također vide i prednosti drugačijeg života od onog uobičajenog prije pandemije i želju da svijet nešto nauči iz svega.

Ovo istraživanje ima ograničenja povezana ponajprije $s$ uzorkom istraživanja. Iako bismo voljele da naša analiza uključuje iskustva žena pripadnica različitih klasa, pozivu na istraživanje u najvećoj su se mjeri odazvale visokoobrazovane stručnjakinje. Njihovi nam odgovori pokazuju kako je prekarna pozicija žene prisutna i kod visokoobrazovanih žena, kao i da situacija izolacije služi kao jasan lakmus izražene preopterećenosti žena u ulozi roditeljice, njegovateljice i emotivne zbriniteljice obitelji, kao i kućne pomoćnice i hraniteljice. No, nedostatak usporedbe sa ženama drugih klasa ostavlja, primjerice, otvorenim pitanje brige za ekonomsku neizvjesnost u nižim klasama tijekom izolacije, zatim koliko je za njih lagodan život u izolaciji i je li to vrijeme hobija i stjecanja novih vještina, koliko je prisutno promišljanje o udobnosti usporavanja života te naposljetku koliko je prisutna društvena kritika i kakvog je ona sadržaja. 


\section{Literatura}

1. Abdallah, S. and Jeffrey, K. (2014). Hands-on communities: The community and well-being benefits of learning and sharing practical skills. London: New Economics Foundation.

2. Abdallah, S.; Mahony, S.; Marks, N.; Michaelson, J.; Seaford, C.; Stoll, L.; Thompson, S. (2011). Measuring our progress: the power of well-being. London: New Economic Foundation.

3. Aldrich, D. P. (2012). Building Resilience: Social Capital in Post-Disaster Recovery. Chicago: University of Chicago Press.

4. Barrett, M. and McIntosh, M. (2015). The anti-social family. Verso Trade.

5. Beckert, J. and Suckert, L. (2020). The future as a social fact. The analysis of perceptions of the future in sociology. Poetics, 101499. https://doi.org/10.1016/j. poetic.2020.101499.

6. Brundiers, K. (2018). Educating for post-disaster sustainability efforts. International journal of disaster risk reduction, 27: 406-414.

7. Bonal, X. and Gonzalez, S. (2020). The impact of lockdown on the learning gap: family and school divisions in times of crisis. International Review of Education, 66: 635-655.

8. Bourdieu, P. (1984). Distinction: A social critique of the judgement of taste. Harvard university press.

9. Comfort, L. K. 1999. Shared Risk: Complex Systems in Seismic Response. Amsterdam: Pergamon.

10. Coote, A. (2015). People, planet, power: toward a new social settlement. The International Journal of Social Quality, 5 (1): 8-34.

11. Coote, S.; Hogan, N. and Franklin, S. (2013). Falls in people with multiple sclerosis who use a walking aid: prevalence, factors, and effect of strength and balance interventions. Archives of physical medicine and rehabilitation, 94 (4): 616-621.

12. Czymara, C. S.; Langenkamp, A. and Cano, T. (2020). Cause for concerns: gender inequality in experiencing the COVID-19 lockdown in Germany. European Societies, 1-14. https://doi.org/10.1080/14616696.2020.1808692.

13. Fodor, É.; Gregor, A.; Koltai, J. and Kováts, E. (2020). The impact of COVID-19 on the gender division of childcare work in Hungary. European Societies, $1-16$.

14. Goodwin, N. (2010). If US consumption declines will the global economy collapse?, in: Ekström, K. and Glans, K. (Eds.). Changing consumer roles. New York: Routledge.

15. Grasso, M.; Klicperová-Baker, M.; Koos, S.; Kosyakova, Y.; Petrillo, A.; Vlase, I. (2021). The impact of the coronavirus crisis on European societies. What have we learnt and where do we go from here?-Introduction to the COVID volume. European Societies, 1-31.

16. Hillebrandt, F. (2014). Soziologische Praxistheorien: Eine Einführung. Wiesbaden: Springer. https://doi.org/10.1007/978-3-531-94097-7. 
17. Hipp, L. and Bünning, M. (2020). Parenthood as a driver of increased gender inequality during COVID-19? Exploratory evidence from Germany. https://doi.or $\mathrm{g} / 10.1080 / 14616696.2020 .1833229$.

18. Łukianow, M.; Głowacka, M.; Helak, M.; Kościńska, J.; Mazzini, M. (2021). Poles in the face of forced isolation. A study of the polish society during the COVID-19 pandemic based on 'Pandemic Diaries' competition. European Societies, 23 (sup1): S844-S858.

19. Michaelson, J.; Abdallah, S.; Steuer, N.; Thompson, S.; Marks, N.; Aked, J.; Cordon, C.; Potts, R. (2009). National Accounts of Well-being: bringing real wealth onto the balance sheet. http://www.nationalaccountsofwellbeing.org/ learn/download-report.html.

20. Möhring, K.; Naumann, E.; Reifenscheid, M.; Wenz, A.; Rettig, T.; Krieger, U.; Friedel, S.; Finkel, M.; Cornesse, C.; Blom, A. G. (2020). The COVID-19 pandemic and subjective well-being: longitudinal evidence on satisfaction with work and family. European Societies, 1-17. https://doi.org/10.1080/14616696. 2020.1833066.

21. National Research Council (2012). Community Resilience: A National Imperative. Washington, DC: National Academies Press.

22. Nicolini, D. (2009). Zooming in and out: Studying practices by switching theoretical lenses and trailing connections. Organization Studies, 30 (12): 13911418. https://doi.org/10.1177/0170840609349875.

23. Norris, F. H.; Stevens, S. P.; Pferrerbaum, B.; Wyche, K. F.; Pfefferbaum, R. L. (2008). Community Resilience as a Metaphor, Theory, Set of Capabilities, and Strategy for Disaster Readiness. American Journal of Community Psychology, 41: $127-50$.

24. Ohlbrecht, H. and Jellen, J. (2020). Unequal tensions: the effects of the coronavirus pandemic in light of subjective health and social inequality dimensions in Germany. European Societies, 1-18. https://doi.org/10.1080/14616696.2020 .1852440 .

25. Patton, M. Q. (2007). Sampling, qualitative (purposive). The Blackwell encyclopedia of sociology.

26. Plant, E. A.; Hyde, J. S.; Keltner, D.; Devine, P. G. (2000). The gender stereotyping of emotions. Psychology of Women Quarterly,24 (1): 81-92.

27. Reckwitz, A. (2002). Toward a theory of social practices. a development in culturalist theorizing. European Journal of Social Theory, 5 (2): 245-265. https:// doi.org/10.1177/136843102222254324.

28. Rhodes, T. and Lancaster, K. (2020) Mathematical models as public troubles in COVID-19 infection control: Following the numbers. Health Sociology Review, 29 (2): 177-194. https://doi.org/10.1080/14461242.2020.1764376.

29. Risi, E.; Pronzato, R. and Di Fraia, G. (2020). Everything is inside the home: the boundaries of home confinement during the Italian lockdown. European Societies, 1-14. https://doi.org/10.1080/14616696.2020.1828977. 
30. Schatzki, T. R. (2005). Peripheral vision: The sites of organizations. Organization studies, 26 (3): 465-484.

31. Schmid, L.; Wörn, J.; Hank, K.; Sawatzki, B.; Walper, S. (2020a). Changes in employment and relationship satisfaction in times of the COVID-19 pandemic: Evidence from the German family Panel. European Societies. https://doi.org/10. 1080/14616696.2020.1836385.

32. Stiglitz, J. E. (n.d.). Report by the Commission on the Measurement of Economic Performance and Social Progress. www.stiglitz-sen-fitoussi.fr. (Retrieved January 4, 2021)

33. Tierney, K. (2019). Disasters: A Sociological Approach. Policy Press: Cambridge.

34. Uekusa, S. (2018). Rethinking resilience: Bourdieu's contribution to disaster research. Resilience, 6 (3): 181-195.

35. Werron, T. and Ringel, L. (2020). Pandemic Practices, Part One. How to Turn "Living Through the COVID-19 Pandemic" into a Heuristic Tool for Sociological Theorizing. Sociologica, 14 (2): 55-72. https://doi.org/10.6092/issn.1971$8853 / 11172$.

36. Zaretsky, E. (2012). Capitalism, the family, and personal life (pp. 72-128). KG Saur. 
Izvorni znanstveni rad

\title{
Despair and Happiness in the Time of Unhappiness: The Variety of Women's Experiences of Quarantine during the COVID-19 Pandemic
}

\author{
Marija Brajdić Vuković \\ Institute for Social Research in Zagreb, Croatia \\ e-mail: marija@idi.hr \\ Karin Doolan \\ University of Zadar, Department of Sociology, Croatia \\ e-mail:kdoolan@unizd.hr
}

\begin{abstract}
The article draws on concepts such as pandemic social practices, economy of care and capitals in order to explore women's feelings, thoughts and practices during the first wave of the COVID-19 pandemic lockdown in Croatia in April 2020. It is based on on-line research which gathered the responses from 213 women of different age groups who, based on their educational level and profession, belong to the dominant class. The research consisted of a series of open questions which enabled the collection of personal narratives. Our study participants noted key words they felt captured the world, their family and friends, and themselves during the pandemic as well as what their daily lives look like during lockdown and what thoughts they are having about their lives in the present and future. Our findings show that responsive pandemic practices shape everyday life during lockdown, that life during lockdown is routinised, emotionally complex, that women with small children are overburdened and exhausted and that lockdown sharpens gender inequalities. We find that being financially secure adds to our participants' resilience, as well as that some of them are in precarious positions and concerned about their financial prospects. Good relationships with others and hobbies, which include on-line yoga and on-line cultural practices, are also conducive to their resilience. According to the women participating in our study, the pandemic may result in an economic crisis, deepening inequalities, curbed personal freedoms and alienation among people, but it may also lead to more concern for nature, a political and economic shift to a more sustainable society and strengthened solidarity.
\end{abstract}

Key words: women's narratives, lockdown, COVID-19, pandemic practices, capitals, gender inequalities. 